\title{
Čłyři dimenze individualizmu v environmentální perspektivě
}

\section{Four dimensions of individualism in an environmental context}

\author{
Hana Librová
}

\begin{abstract}
This article aims to bring a fuller understanding of individualism to the environmental discourse. Popular debates as well as professional writings of environmentalists tend to equate individualism with egoism, a lack of willingness to change environmentally risky behaviours, the consumerist lifestyle, and a self-centred focus on privacy. This article utilizes a typology of semantic dimensions of individualism presented by American sociologist Steven Lukes. This typology allows us to consider the environmental context of individualism in a broader sense.

Based on an historical and semantic analysis, Lukes proposes eleven dimensions of individualism, namely: human dignity, autonomy of decision-making, privacy, personal development, abstract individual, as well as political, economic, religious, ethical, epistemological and methodological individualism.

This article focuses on the first four dimensions of individualism and suggests that this more broadly conceptualised individualism does not necessarily reflect the ecologically risky attitudes of a selfish individual, but that it brings, in many respects, environmentally friendly elements into attitudes toward nature and everyday behaviour.
\end{abstract}

KEYWORDS environmental ideology, individualism, semantic Dimensions, way of life

\section{Nesnáze s pojmem individualizmus; Lukesova sémantická typologie}

Vztah jedince a společnosti je ve společenských vědách frekventovaná látka. Sociologie používá pro postižení jeho proměn slovo ,individualizace“; psychologie, filozofie, historie a další vědy častěji hovoří o ,individualizmu“.

Nad obsahem pojmu individualizace se sociologové relativně shodnou. Chápou jej jako přechod od tradiční, převážně zemědělské pospolitosti ke společnosti průmyslové, což byl proces charakteristický pro 18. a 19. století. Uvolňovaly se tradiční vazby, sociální role a kulturní normy spojené s třídou, pohlavím, náboženstvím a lokalitou, rostla osobní svoboda jednotlivce a možnost jeho voleb a autonomních rozhodnutí; život se stal otevřenější a pružnější.

Sociální studia. Fakulta sociálních studií Masarykovy univerzity, 3/2009. S. 11-29. ISSN 1214-813X.

1 Tento text byl připraven jako součást projektu Grantové agentury ČR „Individualizace životního způsobu v environmentální perspektivě“, který je evidován pod číslem 403/07/0804. 
Individualizace však kladla na jedince nové požadavky, vystavila ho nepřehledným mechanizmům a novým formám společenské kontroly; jeho život začaly v rostoucí míře určovat podmínky trhu a státní instituce (srov. Keller 2004). Jindy mají sociologičtí autoři v souvislosti s individualizací na mysli procesy 20. a 21. století, kdy se na jedné straně ještě více uvolňují sociální vztahy jedinců, pokračuje atomizace rodin, mění se způsob spotřeby a způsob trávení volného času, a na druhé straně se stupňuje vliv nepřehledných mechanizmů na jedince, sociální struktura získává v rostoucí míře abstraktní charakter, sílí význam světově založených sítí (tamtéž, dále např́klad Bauman 1999, Beck a Beck-Gernsheim 2002 a další).

Někteří sociologové zdůrazňují odlišnost pojmů individualizmus a individualizace (např. Beck a Beck-Gernsheim 2002: 202), přičemž pojem „individualizace“ spojují s objektivně probíhajícími procesy moderní společnosti; spíše než vlastnosti a postavení jedince má vyjadřovat strukturální transformaci sociálních institucí. Je však příznačné, že po tomto přísném rozlišení sami autoři často $\mathrm{v}$ tomtéž textu užívají oba pojmy ve shodném nebo podobném významu, např́íklad Beck píše v pojednání o individualizaci o kooperativním či altruistickém individualizmu (tamtéž: 211-212). Bez ohledu na úvodní proklamace, apelující na rozlišování, je individualizace většinou implicitně chápána jako proces vedoucí k individualizmu, přičemž analytická pozornost bývá věnována spíš individualizmu. Ukazuje se, že striktní oddělování obou pojmů je neživotné.

Sledujeme-li literaturu zabývající se individualizmem, vidíme, že snahy o definiční vymezení narážejí na šíri tohoto fenoménu. Jejich společným jmenovatelem bývá truizmus - vyjádření, že individualizmus je postoj, představa či názor, podle něhož má jednotlivec větší význam, než jakýkoliv kolektivní útvar. Př́lišná obecnost a malá sdělnost této definice vede badatele k tomu, že přicházejí s vymezením enumerativním. Český Velký sociologický slovník uvádí tři roviny pojmu „,individualizmus“ - individualizmus jako postoj, který dává přednost lidské osobnosti před všemi kolektivy, jako politická doktrína, která zdůrazňuje práva jednotlivce a vyžaduje omezení regulující moci státu, a jako filozofická koncepce, podle níž je individuum cílem o sobě a jeho posláním je seberealizace a sebekultivace (1996: 421-422).

K autorům, kteří si všimli obtíží spojených s užíváním slova individualizmus, patř́i americký sociolog Steven Lukes. Je př́íznačné, že tento autor, jehož práce o individualizmu jsou často citovány, sám obecnou definici neuvádí. Konstatuje, že jde o pojem, který zahrnuje velmi širokou varietu významů, který se vyznačuje značnou neurčitostí. Díky asociaci se svobodou má slovo „individualizmus“ velkou evokativní emotivní sílu a přitažlivost pro vizionáře (Lukes 2006: 1).

Z této pojmové a obsahové neurčitosti se Lukes snaží vymanit analytickými postupy. Formuluje sémantickou bilanci základních dimenzí, které vkládáme do slova „individualizmus“, když je vyslovujeme nebo když je slyšíme. ${ }^{2}$ Jde o asociace, které vznikly a byly formovány historicky $\mathrm{v}$ rámci národních kultur.

Lukesova konotační typologie je postavena na př́kladech, většinou citátech, charakterizujících určitou dimenzi individualizmu. Nejde pritom o jejich logickou či chronologickou návaznost, ale o charakterizační přiléhavost, která může být dobrým základem pro operacio-

2 Lukesova jedenáctibodová klasifikace je založena na logice podobné stručnějšímu pojetí zmíněného Velkého sociologického slovniku. 
nalizační postupy ve výzkumu. Pro větší sdělnost Lukes jednotlivé dimenze individualizmu doplňuje názory, které se $\mathrm{v}$ historii stavěly vůči individualizmu negativně. Jak je u typologických charakteristik samozřejmé, nevyznačuje ani Lukesova typologie individualizmu uzavřené vlastnosti. $\mathrm{V}$ realitě je pravděpodobný jejich průnik, vzájemné kombinace různých intenzit jeho složek. Body 1 až 11 typologie tak vyjadřují spíše konotované dưrazy, než izolované dimenze individualizmu.

V Lukesově typologii je individualizmus koncept vyjadřující

důstojnost a jedinečnost člověka,

autonomii,

soukromi,

seberozvoj,

abstraktní individuum,

individualizmus politický,

individualizmus ekonomický,

individualizmus náboženský,

individualizmus etický,

individualizmus epistemologický,

individualizmus metodologický. ${ }^{3}$

$\mathrm{V}$ tomto článku se pokusíme použít některé Lukesovy kategorie individualizmu k tomu, abychom naznačili některé z možných vztahů individualizmu k environmentálním problémům. Jak podrobněji dokládá V. Pelikán (2009), toto široké téma doposud nebylo v sociologické literatuře explicitně reflektováno a analyzováno. Pokud si jej všímá odborná environmentalistická literatura a environmentalistická ideologie, chápou individualizmus ve značně redukovaném významu (tamtéž).

\section{Redukovaný pohled na individualizmus v environmentálním myšlení}

Slovo ,individualizmus“ můžeme používat jako odborný pojem, ale v intuitivní podobě se stalo i součástí běžné mluvy, vyjadřování v každodenních situacích. Analogicky platí, že je nacházíme jak $\mathrm{v}$ odborné environmentalistické literatuře, tak $\mathrm{v}$ debatách ekologických aktivistů a jejich sympatizantů. Slovo ,individualizmus“ tam bývá užíváno jako předem hodnotící nálepka, která označuje sobecké myšlení a jednání prohlubující ekologickou krizi. Environmentální myšlení vysoce oceňuje principy kolektivizmu, často jeví nostalgii po tradiční společnosti. Takto nahlíženo, moderní „individualista“ není ochoten vstupovat nejen do mezilidských solidárních vztahů, ale ani do vztahů vytvářejících jednotu s prŕrodou.

3 Pro environmentální zkoumání by bylo nosné doplnit ještě dimenzi individualizmu, kterou Lukes neuvádí. Spočívá v odpoutáni od lokality, ve vyčlenění z místa, ve ztrátě domova. Jde o typ individualizmu, na nějž kriticky upozorňují zejména konzervativně orientovaní environmentalisté (viz napríklad Scruton 2008). 
M. M. Bell (Bell a Carolan 2004: 228) chápe, v asociaci na známou Hardinovu metaforu, ${ }^{4}$ celý environmentální problém jako „tragédii individualizmu“.

Ve srovnání s šíři dimenzí a sémantických významů individualizmu, na něž poukazuje svou klasifikací Lukes, jde o nápadnou obsahovou redukci, omezení individualizmu na etickou dimenzi. ${ }^{5}$

Jaké jsou kořeny negativního názoru environmentalistů na individualizmus? Necháme-li stranou, že individualizmus bývá převážně záporně konotován v obecné mluvě vůbec, v případě environmentálního myšlení vidíme přinejmenším tři specifické zdroje: První je historickým dědictvím - ochrana prrírody byla součástí dodnes vlivného levicového aktivizmu 60. a 70. let, který ji rétoricky spojoval s kritikou individualistického kapitalistického liberalizmu. Druhým zdrojem ideového př́klonu environmentálního myšlení ke kolektivistickému principu je zvláštní kombinace rousseauovské myšlenkové tradice, vzhlížející k prŕírodě jako učitelce, a domněle vědeckých argumentů. Jedinec, inspirován př́rodou, se má podrobit jednotnému řádu, který spočívá ve stabilitě př́rodních systémů. Třetí typický argument, odmítající individualizmus, má konzervativní povahu. Opírá se o mýtus o vlídném chování zemědělské pospolitosti minulých staletí k prŕrodě: když se pod vlivem individualizace, industrializace a urbanizace tradiční pospolitost rozpadala, nevratně prý zanikal i prrirozený láskyplný vztah lidí ke krajině.

Takový pohled na individualizmus a kolektivizmus je výsledkem několikanásobného nedorozumění či spíše nepochopení, které se mezi environmentalisty traduje po generace. Při bližším pohledu sotva tyto argumenty obstojí. Za prvé: Jakkoliv se alternativní hnutí 60. a 70. let minulého století explicitně hlásila ke kolektivizmu, byla spíš založena právě na individualizmu svých účastníků a často anarchisticky orientovaných inspirátorů, než na rysech tradiční společnosti (Tomek a Slačálek 2006). Ostatně, historický zrod zájmu o př́rodu a její ochranu př́rody je třeba situovat hlouběji, do 19. století. Tehdy významně tkvěl jak v konzervativních hodnotách (Scruton 2008), tak v romantickém individualizmu (Librová 1988). Za druhé: Současné biologické vědy nesdílejí představu o celostní povaze a stabilitě ekosystémů; kritizují ji jako mechanistickou. Zdůrazňují nerovnovážnost a heterogenitu př́rodních procesů (viz např́klad Konvička 2002). Za třetí: Konzervativní romantická představa o láskyplném vztahu staré pospolitosti ke krajině zapomíná, že ekologická příznivost tradičního hospodaření byla dána slabými technologiemi, nebyla záměrem starého zemědělce.

Obecně vyjadřovaný morální odsudek individualizmu bývá v environmentálním diskurzu provázen stereotypními příklady z každodenního životního zpo̊sobu: individualizmus plodí konzumní mentalitu, sklon k získávání a hromadění předmětů, neochotu sdílet domácnost a její vybavení, lpění na individuální dopravě, nezájem lidí o veřejné dění a vůbec neochotu vstupovat do solidárních vztahů. Jen některé z těchto rysů jsou empiricky doloženy; např́klad ekonomická analýza (Røpke 1999) prokázala plýtvavost malých domácností, jejichž početní růst je demografickým důsledkem individualizace.

Hardin píše o „tragédii obecní pastviny“ (Hardin 1968).

Jde navíc i o redukci uvnitř Lukesovy kategorie etického individualizmu - viz rámeček na konci textu. 
Všimněme si zdánlivého paradoxu: Jde o tytéž rysy životního způsobu, které jindy environmentalisté uvádějí jako výsledek potlačení svobodných individuálních voleb, jako výsledek tlaku společnosti na jedince. Paradox je vysvětlen, přijmeme-li Simmelovo pojetí, rozlišující individualizmus (doslova, individualitu“) kvantitativní a kvalitativní. Individualizmus kvantitativní znamená rovnost, osvobození z vazeb stavovské a tradiční pospolitosti, ale zároveň unifikaci individuí, jejich podřízení tlakům moderní společnosti. Podle některých autorů je život jedince determinován všemocným systémem a byrokratickými strukturami do té míry, že se o individualizmu vlastně nedá hovořit. Slovy Horkheimera a Adorna (1971) je spíš na místě hovořit o pseudoindividualizmu masové společnosti.

Shrňme: Environmentalistický odsudek individualizmu má dva rysy: pohlíží na individualizmus téměř výlučně v dimenzi etické a všímá si pouze tzv. individualizmu kvantitativního či pseudoindividualizmu.

Tento text se pokouší environmentalistický náhled rozšířit. Jde v něm o zamyšlení nad individualizmem, které se bude opírat o dimenze definované Lukesem. $Z$ jeho jedenácti kategorií individualizmu jsme zvolili čtyři - distojnost a jedinečnost jedince, autonomii, soukromí a seberozvoj. Stranou necháme ostatní z výše uvedených Lukesových kategorií; pro úplnost se o nich heslovitě zmíníme v rámečku na konci textu.

Naše čtyři kategorie se relativně prrímo podílejí na utváření postojů jedince $\mathrm{k}$ př́rodě (mají vztah k environmentální etice) a na rozhodování jedince o životním způsobu, environmentálně významné sféře života, $v$ níž má individuum, na rozdíl od sféry technologické, makroekonomické nebo politické, relativně svobodnou volbu. Pokud bychom setrvali u zmíněné inspirativní klasifikace G. Simmela (1922: 541-543), zvolili jsme pro náš další text rysy individualizmu, které utvářejí kvalitativní individualitu. Ta je výsledkem snahy vymanit se volbou životního způsobu z determinací sociální, ale i psychologické a biologické povahy, snahy jedince záměrně se distancovat od většinové společnosti. Aniž to environmentalisté reflektují, je kvalitativní individualita kategorií, která odpovídá jimi oceňovanému nonkonformizmu.

\section{Dimenze a konotace individualizmu v environmentální perspektivě}

\subsection{Dưstojnost člověka}

Na prvním místě Lukes uvádí jako významnou dimenzi individualizmu di̊stojnost lidské bytosti. Hodnotu důstojnosti spojuje s jedinečností. Jedinec je důstojný ve své neopakovatelnosti; jeho hodnota se neodvozuje od významu celku.

Tento náhled byl prrítomen již v antických společnostech, zejména na rozhraní klasického a helénistického období (Bednaříková 2008, Kysučan 2007). Zásadně je obsažen v křest’anském myšlení: „Cokoliv jste neučinili jednomu z těchto nepatrných, mně jste neučinili“ (Matouš 25,45). Zatímco starozákonní judaizmus stavěl do popředí kmen, vyvolený národ, Nový zákon zdůraznil zájem Boha o jednotlivce: „Potom už není Řek a Žid, obřezaný a neobřezaný, barbar, divoch, otrok a svobodný - ale všechno a ve všech Kristus“ (List Pavla ke Koloským 3,11). Podle Burckhardta (1913) je význam jedinečnosti člověka, zejména člověka-tvůrce, charakteristický pro italskou renesanci. Jejím dědictvím je obava jedince, že by 
se komukoliv podobal: „Odvažuji se domnívat, že nejsem stvořen jako kdokoli z těch, kdo existují. Nejsem-li lepší, jsem alespoň jinaký“ (Rousseau 1978: 19). V 19. století, s postupujícím procesem individualizace, se jedinečnost člověka stává všeobecně přijímanou hodnotou. V extrémní podobě ji formulovali někteří anarchističtí myslitelé, např́iklad Max Stirner. Ten chce jedince vymanit z jakýchkoliv vnějškových podřizeností a odmítá také, aby byl jedinec zahrnován pod obecnou ideu člověka.

V evropské kultuře sotva uslyšíme hlasy, které by jedinečnost člověka zpochybňovaly. Určitě však lze zaslechnout takové, které varují před přeceněním jejího významu, varují před sociální anomií. ${ }^{6} \mathrm{~V}$ tomto pojetí znamená důraz na jedinečnost a nezávislost individua ohrožení společnosti a jejího řádu. Jednotlivec je součástí celku, prvkem, který se má prosperitě celku podřídit.

Jak již bylo naznačeno, environmentální myslitelé se přímo nebo neprrímo hlásí právě $\mathrm{k}$ této druhé ideové a postojové linii, přičemž pojetí celku rozšiřují; patří do něj nejen lidské bytosti. Environmentální myšlení vysoce oceňuje participaci, solidaritu a společenství. V jeho pojetí se hodnoty neodvozují od jedinečných jednotlivých bytostí ani od jednoho biologického druhu, ale od ekosystému. Slavná a v okruhu environmentalistů často citovaná je věta Alda Leopolda, která vyjadřuje jádro tzv. ekosystémové etiky: „Určitá věc je správná, když směřuje k zachování celistvosti, stability a krásy biotického společenství. Směřuje-li jinam, je špatná“ (Leopold 1999: 25, zdůraznila HL).

Přesto nemůžeme říci, že by princip jedinečnosti v environmentální ideologii nebyl př́itomen. Jiné proudy environmentální etiky hodnotu jedinečnosti obsahují, výslovně biocentrický individualizmus Paula Taylora (1986). Jak upozorňuje E. Kohák, takzvaná etika úcty k životu Alberta Schweitzera vyjadřuje význam života každé jednotlivé živé bytosti (Kohák 1998: 84-92). S její aplikovanou podobou se setkáváme ve snahách o ochranu zvírat, např́klad $\mathrm{v}$ práci záchranných stanic pečujících o handicapované jedince nebo v ochraně zvířat před týráním - činností, které jsou z hlediska ekosystémového přístupu pošetilé a sentimentální. Velmi zajímavé je sledovat, jak se proměňovaly původní ideje rodící se institucionální ochrany prrírody, např́klad ochrany starých stromů, ale i kulturních památek. Postupně v nich byla oslabována kolektivní vlastenecká motivace, dokládající národní význam a konzervativní úctu k tradici předků, a začíná být zdůrazňována jedinečnost těchto objektů - vlastně subjektů - a jejich neopakovatelná historie (Riegl 2003: 79).

Nejde však jen o oblast environmentální etiky. Filozofující biologie dnes oživuje otázku po smyslu a hodnotě individua $\mathrm{v}$ př́rodě, po niternosti a sebeprezentaci či sebevyjádření živých organizmů (Komárek 2008). Podle Adolfa Portmanna je každý živočich ,záhadný, složitý útvar s předlouhou historií, bytost, která stojí ve světě coby prožívající subjekt, která má vnitřní život. A i když je to pro výzkumníka těžko pochopitelné, představuje činné Selbst“ (Portmann 2008: 63).

Z hlediska jedinečnosti jsou zajímavé dosavadní sociologické poznatky o podstatě a motivacích ekologicky př́znivých životních stylů (Librová 1994). Jakkoliv bývají označovány jako projev kolektivistického a solidárního postoje a jakkoli se k němu často samy hlásí, ve sku-

6 V sociologické interpretaci je třeba připomenout např́iklad názory E. Durkheima, T. Parsonse a N. Luhmanna. 
tečnosti se na jejich utváření podílí především individualizovaný záměr, touha po naplnění jedinečnosti uprostřed nivelizované masové společnosti pseudoindividuí, slovy Simmelovými uprostřed kvantitativních individualit (viz výše). Podobně zřejmě platí, že environmentálně orientované kolektivity, komuny, ekologická hnutí a jejich aktivity jsou spíše výsledkem iniciativy jedinců, dílem jejich spontánního nebo vědomého tíhnutí $\mathrm{k}$ jedinečnosti, než prípadem tradičního pospolitostního chování (Johanisová 2005).

Na tom nic nemění fakt, že ekologicky příznivý životní způsob mívá rysy solidarity a kolektivizmu, které vždy znamenají ochotu slevit z výlučné jedinečnosti. I zde jde totiž o vědomou volbu, o zámérnou reintegraci, jako projev kvalitativní individualizace (Librová 2009).

Viděli jsme, že jedinečnost lze vztáhnout i na jiné než lidské bytosti jen s určitou licencí; v př́ípadě úžeji chápané důstojnosti je takové rozšiřrení ještě problematičtější. Není individuální důstojnost jenom výsadou člověka?

Hodnota jeho důstojnosti je vyjádřena ve slovech J. J. Rousseaua: „Človek (...) je př́lišs ušlechtilý tvor, než aby mohl sloužit jako nástroj pro druhé“ (dle Rousseau 1982: 456), ${ }^{7}$ a ve slavném výroku I. Kanta: „Jednej tak, abys používal lidství jak ve své osobě, tak i v osobě každého druhého vždy zároveň jako účel a nikdy pouze jako prostředek“" (dle Kant 1976: 75). Tyto ideje se staly pevnou součástí sociálního a etického myšlení dnešní doby a jsou základem konceptu lidských práv.

Z environmentálního hlediska však může být kategorie lidské důstojnosti chápána jako zásadní kámen úrazu. Důstojnost je totiž považována za atribut lidství, za výsadní vlastnost, jíž se člověk liší od ostatních bytostí. Důsledkem důstojnosti, slovy Rousseauovými „Vznešenosti“, jednotlivého člověka pak může být postoj nadřazeného postavení vůči přírodě. Humanismus, který navázal na Aristotelovu představu hierarchičnosti prrírodních tvorů (obsaženou v tzv. řetězci bytostí), chápal lidskou duši jako „největší zázrak př́írody“, „,tř̌edobod všech věcí“ (Kristeller 1972). ${ }^{8}$ Tento postoj přispěl k utváření takzvaného antropocentrismu a ryze účelového jednání lidí vůči př́rodě, na němž stojí úspěch civilizace. Podle některých environmentalistů je toto pojetí lidské důstojnosti hlavní př̌́činou konfliktu mezi člověkem a prírodou a zásadní překážkou ve vytvoření adekvátního př́stupu $\mathrm{k}$ přírodě a ke světu vůbec. ${ }^{9}$

Přece však můžeme říci, že v běžné řeči slovo „důstojnost“ užíváme někdy, vlastně překvapivě často, i pro označení vlastností prírodních tvorů. Bývá, podobně jako slovo „majestát“, spontánním intuitivním vyjádřením obdivu $\mathrm{k}$ formátu a dokonalosti velkých savců a ptáků („důstojnost lva, žirafy, orla“), napadá nás při pohledu na velikost hor. O ztrátě důstojnosti hovoříme při pohledu na zviŕre držené v zajetí.

7 Vycházíme ze slovenského překladu, protože česky kniha nevyšla již téměř sto let (1912).

$8 \quad$ Kristeller se zabývá filozofií humanistického novoplatonika Marsilia Ficina. Podobně pohližejí na člověka jiní humanisté, např́iklad G. Manetti, P. della Mirandola.

9 V environmentalistických diskuzích bývá zpochybňováno nejen nadřazené postavení člověka, ale i sám princip hierarchičnosti, který je prý př́rodě cizí. 
Kategorii „důstojnosti zvířat“ je třeba podrobit nepředpojatému filozofickému, sociologickému a historickému, ale i biologickému a etologickému rozboru. Vyjadřuje totiž jednu ze složek lidské percepce př́rody. Na druhé straně si badatel, který se chce vymanit z emocionálního dojmu laického pozorovatele, klade otázku, zda vůbec můžeme a máme opustit evropskou myšlenkovou tradici, která důstojnost přiznala pouze lidským bytostem. D. Dražilová (2005) v práci o etice zoologických zahrad cituje autory, kteří nepochybují a odpovídají jednoznačně kladně, většinou s poukazem na vyspělou inteligenci některých zvířat. Podle jejich radikálního názoru je výlučné přiznání práva na důstojnost lidem projevem diskriminačního speciesismu. Dražilová sama k jednoznačné odpovědi nedospěla, uvádí však řadu zajímavých argumentů, které z různých hledisek otevírají cestu $\mathrm{k}$ diskusi nad dosavadním pojetí důstojnosti. Bohužel nechává bez rozvedení myšlenku postavenou jak na intuici, tak na odborném etologickém přístupu: Zvířata jsou, na rozdíl od lidí, tvorové plně závislí na vnějších podmínkách svého života. O ztrátě důstojnosti zvířat je možno hovořit tam, kde je držíme v nepřirozených podmínkách zajetí, nejnápadněji v cirkusech, ale do značné míry i v zoologických zahradách.

\subsection{Autonomie}

Píše-li Lukes o autonomii jako o druhé z dimenzí individualizmu, má na mysli především autonomii rozhodování, sebeřizení. Individualizmus zde znamená: Člověk je bytost, která není řízena zevně, není determinována; rozhoduje se svobodně a individuálně na základě vlastní úvahy. Lukes zdůrazňuje, jaký vliv měla na evropské myšlení idea autonomie jedince obsažená v Kalvínově důrazu na osobní odpovědnost člověka vưči Bohu, vztahu, který není zprostředkován institucí církve. Osvícenský racionalizmus potom prrináší myšlenku osvobození člověka od závislosti na Bohu, která se završuje s postupujícím sekularizmem.

Sociologické teorie se k této dimenzi individualizmu vztahují dvěma klasickými koncepty: již zmíněným Simmelovým principem kvalitativní individuality a Weberovou kategorií Lebensführung, doslova řízení života ${ }^{10}$ (Weber 1922: 158-163). Obě teorie naznačují, že i ve společnosti podléhající nepřehledným formám společenské kontroly, i v „ocelové kleci“ moderní společnosti, se může člověk svobodně rozhodnout řídit svůj život a přijímat za něj odpovědnost. Schopnost Lebensführung znamená, že jednotlivec dokáže na základě rozvahy odolávat vnějším okolnostem, ale i vnitřní pudovosti, subjektivitě a iracionálním vášním ,přirozeného“ člověka. Dimenze individualizmu, kterou označujeme jako autonomii rozhodování, oponuje jak sociálnímu determinizmu, tak deterministickému pojetí člověka jako tvora, jehož chování je nezměnitelně dáno biologicky či evolučně psychologicky. „Člověk není výsledkovým bytím“ (Jaspers 2008: 151).

Jako environmentálně relevantní příklad pro toto pojetí lidství můžeme uvést vegetariány a zejména vegany, kteří intuitivně ignorují antropologické argumenty poukazující na evolučně danou ,přirozenost“ masité stravy. Aniž to tak formulují, odmítají přistoupit na deterministický př́istup; je jim blízká myšlenka individualistické autonomie - člověk je tím, čím by mohl být (čim chce být), ne tím, co je (jak je určen).

10 O této dimenzi individualizmu a jeho protipólu Lebenskunst (umění života) pojednáme dál, v kapitole o individualizmu jako seberozvoji. 
Častěji se ale v environmentální perspektivě vynořují skeptické soudy a otázky: Právě ekologická krize, dosavadní vývoj vztahu lidí k přírodě, naznačuje, že osvícenská představa o schopnosti člověka racionálně řídit svůj život je naivní; sociobiologové (napřr. Kellert a Wilson 1993, Ridley 2000) tvrdí, že lidský jedinec se vůči př́rodě chová jako bytost determinovaná biologickými a antropologickými konstantami, evolučně danými vlastnostmi a sklony. Mnohé z vrozených vlastností jsou ekologicky riskantní - člověk se v každodenním chování orientuje na krátké časové a prostorové vzdálenosti, na prospěch malé skupiny, má sklon k získávání a k hromadění, řídí se nápodobou. Je lidské jednání dáno sobeckými geny, nebo jsme vưči př́rodě schopni sebereflexe, sebeomezení a odpovědnosti? Do jaké míry je člověk-jedinec schopen na základě poznání ekologických problémů učinit racionální rozhodnutí a změnit chování vưči přrirodě? Není nezbytné, aby sklony jedince byly korigovány sociálními institucemi? Jaká je role výchovy, speciálně environmentální výchovy? Jak silný vliv může na chování jedince mít?

Zpochybnění sebeřízení člověka se netýká jen vlivu biologických, evolučně daných vlastností lidské bytosti. Sociologové durkheimovské výkladové orientace zdůrazňují, že vztah člověka k prírodě je ovlivňován či přímo určen společenskými podmínkami. Otázkou je, do jaké míry je každodenní život - náplň a zpo̊sob pracovních činností, míra a struktura spotřeby či způsob trávení volného času - ovlivněn vnějšími sociálními a ekonomickými faktory, prestiží, tlakem reklamy (Keller 1993). Je člověk schopen překročit roli pracovníka, spotřebitele a rekreanta, do níž je manipulován, a osvojit si na základě autonomního rozhodování roli environmentálně odpovědného občana (Dobson 2000)? Nejsou pokusy jednotlivců o ekologicky příznivější životní způsob pouhým ,individualizovaným romantizmem“? (Suša 1997: 432) Lipovetsky (2007: 17) dokonce soudí, „čím více je spotřebitel vlastním pánem, tím více podléhá diktátu komerce“.

Sebeřízení, nezávislost chování je možné vidět jako ekologicky nadějný, ale i nepříznivý faktor. Jako příznivý v případech, kdy individuum dokáže vzdorovat vnějším tlakům, které jsou vůči př́rodě potenciálně destruktivní. Lze si však představit i individualizmus, který se prosazuje jako gesto vzdoru vůči environmentalisticky orientovaným hodnotám (Librová 2009b). Někteří teologové varují i v souvislosti s ekologickým problémem před autonomií člověka - individualisty, který odmítá omezení „,to nesmíš“; nepřijímá, že je odpovědný za tento svět Stvořiteli (Ratzinger a Seewald 2005: 118, 162).

\subsection{Soukromí}

Jde o významnou složku individualizmu; v běžné řeči na ni bývá individualizmus redukován. Vyjadřuje izolaci jedince, uzavřenost vůči mezilidským vztahům a také důraz na privátní sféru každodenního života, která je uchráněna od zásahů veřejné sféry. Má vztah k ideji negativní svobody (viz např́klad Berlin 1999). Soukromí cenili vysoko epikurejci ${ }^{11}$ a jeho význam byl zdůrazněn $\mathrm{v}$ době renesance a reformace.

11 Soukromí, jako sféra oddělená od veřejného života, nebylo v antické společnosti ceněno vždy. V jejím klasickém období patřil k plnému lidství podíl na životě obce. Do veřejné sféry nebylo dovoleno vstoupit otrokům; privátní dimenze člověka byla chápána jako oblast nutnosti, nesvobody. 
Soukromí ve fyzickém smyslu bylo od pradávna spojováno se soukromím duchovním. Soukromou sféru duchovního života zdůraznilo Augustinovo Vyznání a dál ji kultivovaly některé proudy křest’anské spirituality, zejména mysticizmus. V jeho pojetí je kontakt s Bohem privátní a tajné povahy; nedosáhnou jej ti, kteří milují svět.

Pro environmentalistický pohled na individualizmus je typické, že orientaci člověka na soukromí chápe zúženě v negativním smyslu jako výraz sobectví. Tento typ individualizmu je kritizován např́iklad v hesle NIMBY - Not In My Backyard, které ironizuje neochotu pečovat o svět, který leží mimo území bezprostředního zájmu jedince. Jako symbol individualistické orientace na soukromí bývají uváděny ploty mezi privátními pozemky, znemožňující lidem i zvířatům volný pohyb v krajině. Jindy slyšíme o „bunkrové mentalitě“ automobilismu. Auto vyjíždějící z podzemní garáže poskytuje řidiči dokonalou ochranu vưči sociálnímu okolí, jeho komunikace s vnějším světem se omezuje na gesta. Podobně se důraz na soukromí pojí se zájmem o bezpečnostní techniku, která umožňuje hermeticky se uzavřít v bytě před světem.

Otázky soukromí jsou významné pro studium environmentálně orientované sociologie bydlení. Tematika suburbánní expanze městského obyvatelstva do vzájemně izolovaných rodinných domů je v současnosti hojně rozpracovávaná (např́klad Vacková a Galčanová 2008). Výrazem touhy po soukromí, která má environmentální relevanci, je i rostoucí počet malých domácností v pozdně moderní společnosti. Ekonomické analýzy doložily, že hospodaření dvou či tří malých domácností je energeticky i materiálově plýtvavější, než provoz jedné vícečlenné společně hospodařící domácnosti. Pro podobný životní standard jsou náklady na hlavu ve dvoučlenné domácnosti dvoutřetinové oproti domácnosti jednotlivců (Røpke 1999, Sanne 2002: 277). ${ }^{12}$

Environmentálně významná je privátní dimenze i z hlediska osobního vztahu k předmětům. Důraz na soukromí je jednou z příčin, proč narážejí na malý zájem občanské iniciativy podporující sdílení předmětů i půjčovny praček nebo automobilů (Dyas 2000: 71). V každodenním provozu si sdílení ve větší míře neosvojili ani lidé, kteří jinak vykazují ochotu k ekologicky příznivému každodennímu chování. Obecně lze konstatovat, že jsou otevření sociálním kontaktům, ale jen výjimečně za cenu ztráty soukromí (Librová 1994).

I zde je však věc složitější. Sociální psycholožka H. Dittmarová (1992) upozorňuje na existenciální význam vztahu člověka k věcem. ${ }^{13}$ Je možno formulovat hypotézu, že vlastnění předmětů, k nimž má jedinec osobní vztah, které jsou součástí jeho soukromí, brzdí sklon k získávání nových předmětů. Jde totiž o to, že spíše než vlastnění věcí je ekologicky záhubná dynamika jejich obměny, princip kup a vyhod'.

Jaká je role soukromí v životním způsobu kolektivních forem ekologicky prŕznivých životních stylů? Je u jednotlivých skupin pravděpodobně značně rozdílná, variuje podle stupně environmentálně orientované radikality. Jakkoliv environmentalistická ideologie zdůrazňuje význam kolektivizmu, potřeba moderního člověka mít soukromí se prosazuje i zde. Podle rozhovorů s členy komunit je pravděpodobné, že nedostatek soukromí patří a patřil k faktorům ohrožujícím stabilitu těchto uskupení. Tohoto rizika jsou si dnes zakladatelé ekologicky

Situací v české populaci se zabývá Z. Tůmová v textu zveřejněném v tomto čísle Sociálních studií. 
orientovaných komunit vědomi a plánují společný život na základě respektu k soukromí (Kramosilová 2009).

A konečně, $v$ environmentálních souvislostech nesmíme zapomenout na vystupňovanou podobu soukromí, na samotu. V historii sehrála významnou roli v utváření prírody a krajiny jako estetické a sociální hodnoty (Librová 1988). V percepci př́rody a krajiny je význam samoty nepochybný dodnes. Dnešní environmentálně vnímaví a motivovaní samotáři jsou dvojí povahy, tak jako bylo poustevnictví od svých počátků, kdy se utvořil vedle proudu samoty individuální proud klášternické samoty hromadné.

\subsection{Seberozvoj}

V perspektivě seberozvoje je jedinec chápán jako tvor nadaný schopností sebekultivace, seberealizace. Směřování $\mathrm{k}$ dokonalosti bývá dokonce nahlíženo jako vlastní podstata člověka. V německém romantismu19. století samo slovo Individualität vyznačovalo pravé lidství, kterého lze docílit rozvojem duchovních sil. Charakteristický byl obraz takto pojaté individuality v umění a metafyzice (Novalis, Schlegel, Schleiermacher).

Seberozvoj těsně souvisí se třemi výše uvedenými dimenzemi kvalitativního individualizmu - s jedinečností (3. 1.), s autonomií rozhodování (3. 2.), se soukromím (3. 3.). Lukesova kategorie seberozvoje se vztahuje k tzv. pozitivní svobodě. Zatímco negativní svoboda jedince uvolňuje od vnějších vazeb a poskytuje mu soukromí, pozitivní svoboda člověka naplňuje.

Na základě obecných sociologických teorií lze odlišit dvě varianty seberozvoje: První má povahu systematického racionálního zvažování a rozhodování o životním způsobu, které Max Weber (1922: 158-163) označuje jako Lebensführung - řizení života. Tento typ seberozvoje se a opírá o staré osvědčené hodnoty a dokáže odolávat subjektivním iracionálním sklonům. Lebensführung nespočívá v zájmu o vlastní Já; jednotlivec vytvárí pevnou identitu oklikou, prostřednictvím obětavé a cílevědomé „služby věci“. Představu o utváření života podle estetického hlediska vidí Max Weber jako nejistou či nebezpečnou.

Právě estetizující př́istup je součástí druhé stránky seberozvoje, tzv. umění života Lebenskunst. Dnes v pozdně moderních životních stylech zaživáme jednu z velkých vln, modifikaci starého ars vivendi, hédonistické filozofie, která spočívala v umírněném uživání tělesných a duševních slastí. Jde však jen o podobnost, ne o vědomý návrat. Zastánci umění života totiž tvrdí, že není k čemu se vracet. A také, že ani není třeba usilovat o pevnou identitu. Naopak, je třeba vytvářet nové formy subjektivity permanentně a intuitivně se proměňujícího tzv. pohyblivého individua (Foucault 1987: 250). Aktuálně se s velkým ohlasem u německé veřejnosti věnuje tématu umění života německý filozof a publicista Wilhelm Schmid (1998, 2000, 2007).

Tyto dva teoretické modely seberozvoje mohou být nosné při interpretacích pokusů o ekologicky příznivé životní styly. ${ }^{14} \mathrm{~S}$ určitou licencí můžeme říci, že modelu Lebensführung, řizení života odpovídá typ ekologicky příznivého života, který označujeme jako záměrná

14 Jejich aktéři však většinou nehovoří explicitně o seberozvoji, nějakém druhu sebezdokonalování, natož o „duchovním růstu“, jak to slýcháváme od vyznavačů duchovních alternativ (Librová 1994). 
skromnost (Librová 1994, 2003). Je charakteristický dobrou informovaností o environmentální situaci a o možnostech jejího ovlivňování. Na tomto základě jednotlivci racionálně zvažují své chování a jeho změny. Typické je sledování spotřebního koše vlastní domácnosti, výpočet tzv. ekologické stopy a její cílevědomé zmenšování prostřednictvím sebeomezení. Rysy tohoto životního způsobu je možno vypozorovat u ekologických aktivistů, zejména pokud se pokoušejí o samozásobitelství (Tůmová 2009). Modelu Lebensführung a Weberovy hodnotové racionality odpovídá i to, že se záměrně skromní jednotlivci odvolávají na staré, dnes zapomínané hodnoty,,$^{15}$ a jeví, tvář́ v tvář většinové společnosti, rysy asketického heroizmu.

Četnost tohoto racionálního typu individualizovaného ekologicky příznivého životního způsobu je v populaci nízká (Hobson 2002), ${ }^{16}$ a je na místě hypotéza, že v posledních desetiletích ještě klesá, a to ve prospěch (někdy pokleslého) Lebenskunst, umění žit.

Výrazem umění žít může být způsob života, který bývá označován jako dobrovolná skromnost (Librová 1994). Není založen normativně, jeho nositelé se neřídí environmentálním záměrem, cílevědomým snižováním ekologické stopy. Environmentální motivace je v životním stylu pouze implicitní a neprímá, má často estetizující povahu. Tento typ skromného života tkví v pocitu nezajímavosti a estetické nepatřičnosti konzumního chování a v citlivém vztahu $\mathrm{k}$ př́rodě. ${ }^{17} \mathrm{Na}$ rozdíl od jedinců orientovaných $\mathrm{k}$ Lebensführung tíhnou aktéri Lebenskunst $\mathrm{k}$ sebeomezení a změně spotřebních vzorců intuitivně a improvizovaně. Jejich př́istup dobře ladí s postheroickým duchem postmoderní doby (Petrusek 2006). Výzkumy (Ray a Anderson 2000, Elgin 1993, Librová 1994) konstatují v souborech dobrovolně skromných respondentů nadreprezentovaný podíl profesionálních i amatérských umělců a uměleckých řemeslníků.

( $V$ environmentálních souvislostech individualizace je zde třeba připomenout, že umělci byli a jsou významnými senzibilizátory environmentálního vědomí společnosti. Namátkou připomeňme výrazné individualisty 20. století Jakuba Demla, Jiřího Mahena, Antonína Sovu, Josefa Váchala. Není také náhodné, že řada environmentálních organizací a jejich aktivit se opírá o sympatie a pomoc ze strany umělců..$^{18}$ )

Ekologicky př́iznivé umění žít (Lebenskunst), které bylo historicky a donedávna výrazem kvalitativní individualizace, se v poslední době mění v projev individualizace kvantitativní; stává se masově prrijímanou módou, předmětem komercionalizace, byznysu a reklamy. „Umělec života“ - „kreativní jedinec“, se „ekologickému“ životnímu stylu učí často na základě importovaných duchovních proudů. Není náhodné, že se výše zmíněný W. Schmid (1998) ve své popularizované filozofii Lebenskunst věnuje právě jejím environmentálním sou-

15 V rozhovorech se záměrně skromnými respondenty se často objevuje zmínka o inspiraci skromným životním způsobem „,dědy“ nebo babičky (Librová 1994).

16 K. Hobsonová (2002) na základě rozhovorů zjistila, že v motivacích ekologicky př́znivého života hrají racionální environmentální motivace menší roli než jiné faktory.

17 Zajímavá by mohla být analýza ekologicky zaměřeného časopisu Resurgence, který staví na estetizujícím a uměleckém životním způsobu. Typicky se v schumacherovském duchu věnuje např́íklad renesanci uměleckých řemesel.

18 Máme-li uvést prríklad, nenáhodný je těsný kontakt sdružení ochránců přírody Veronica s brněnskými umělci nebo podpora umělců ekologickým projektům, např́íklad na záchranu bělokarpatských jedlobukových lesů a květnatých luk. 
vislostem. Nápadná je hypertrofie zdravotní argumentace, kult těla, důraz na „zelenou spotřebu“. Charakteristická je nepřítomnost sebeomezení. G. Lipovetsky na četných příkladech ukazuje, jak je zneužito „vnitřní harmonie a rozvinutí psychického potenciálu“; seberozvoj ústí do hyperkonzumu (2007: 17). Se satirickou nadsázkou píše o životním stylu postaveném na kultu seberozvoje D. Brooks (2001).

Jakkoli proklamovaná idea „osobního růstu“ artikuluje environmentální hlediska, ve skutečnosti často naopak přináší negativní dopady na přírodu, naprríklad jako důsledek dovozu biopotravin ze vzdálených oblastí, jako důsledek masového turizmu, ,zážitkových“ outdoorových aktivit, adrenalinových sportů v př́rodě apod. Radikálněji uvažujícími environmentalisty, tíhnoucími k životní formě Lebensführung, bývá tento životní styl odsuzován jako „zelené konzumentství“ či ,zelený snobizmus“. ${ }^{19}$

Zajímavou paradoxní vlastností environmentálně orientovaného individualizmu jako seberozvoje je proces, který můžeme označit jako reintegrace. Jde o to, že jedinci-individualisté na své dráze seberozvoje dříve či později tíhnou k utváření kolektivit. Vytvářejí pevné rodinné svazky, zapojují se do zájmových skupin, staví se do čela kulturního a občanského života v lokalitě bydliště (Librová 1994).

Závěrem je třeba udělat poznámku pro případ, kdy bývá slovo „seberozvoj“ nahrazováno pojmem , seberealizace“. Ten má totiž v environmentálních souvislostech specifický význam, který byl do environmentálního diskurzu vnesen Arne Naessem, autorem konceptu hlubinné ekologie. Seberealizace je tu chápána jako sebepřekračování spočívající v intuitivním i vědomém rozšíření Já ztotožněním s přírodou, se vším mimolidským bytím (Naess 1996).

\section{Závěr}

Intuitivní názory i odborné debaty environmentalistů obsahují četná krátká spojení a dokonce předsudky. Mezi ně patří zúžené chápání individualizmu. Bývá ztotožňován s egoizmem, s neochotou korigovat ekologicky riskantní chování, spotřební životní způsob a sobecké lpění na soukromí. V našem textu jsme použili Lukesovy analytické sémantické kategorie individualizmu, které umožňují nepředpojatý širší a, prripust'me, spravedlivější pohled. Díky nim se můžeme zamýšlet nad environmentálními souvislostmi individualizmu z jiných zorných úhlů.

Můžeme nahlédnout, jaký je význam jedinečnosti ve světě lidí i přírody, bez apriorního rozhorlení pochopíme historickou podstatu ,panského“ postoje vůči přírodě, dokážeme si klást otázky týkající se intuitivního obrazu „důstojnosti zvířete“ či „důstojnosti velehor“. Environmentalistickou ideologií často kritizované soukromí může zprostředkovaně mít, vedle negativních dopadů, i stránky ekologicky př́znivé; jednou z nich je historický fakt, že vystupňované soukromí - samota - sehrálo nezpochybnitelnou roli v ustavení př́rody a krajiny jako estetické a sociální hodnoty.

19 Tento trend by byl empirickému zkoumání relativně snadno přístupný, např́iklad analýzou tzv. lifestylových časopisů, návodových brožurek, nabídek kurzů a pobytů, nebo i přímým pozorováním. 
Chápeme-li individualizmus v dimenzích autonomie rozhodování a seberozvoje, otevírá se nám nový pohled na biologický, ekonomický a společenský determinizmus; můžeme poučeněji a v jemnějším rozlišování nastínit otázku, o níž se v environmentalistických kruzích diskutuje většinou povrchně a v extrémních polohách: je jedinec schopen rozhodnout se pro změnu chování vůči přírodě? Náš text se těmito tématy a otázkami nemohl zabývat v jejich složitosti, pouze nastínil jejich existenci a pokusil se doložit jejich relevanci.

\section{Dodatek}

Další Lukesovy dimenze individualizmu a jejich environmentální relevance

\section{ABSTRAKTNII INDIVIDUUM}

Jde o ontologický pohled na individualizmus. Je člověk svou podstatou společenský tvor, a individualita je jen abstraktní kategorie? Ale zároveň: Společenský život je podle některých autorů kompenzaci základní fyzické/biologické nedostatečnosti (Bauman). Jakmile je člověk existenčně zajištěn, tíhne $k$ individualizmu. Historické studie dokládají, že individualizmus neni pouze fenoménem moderni doby.

Príklad environmentální relevance:

Tyto otázky mohou být významné pro reflexi kolektivistických idejí i pro konkrétni projektování environmentálně založených komunit. Na teoretické úrovni mohou ústit do diskuse o holistických principech fungování př́rody: má smysl uvažovat o individuu ve světě zvírat, prípadně rostlin?

\section{POLITICKÝ INDIVIDUALIZMUS}

Klasicky chápaný liberalizmus, ve vystupňované míre přitomný v anarchizmu. Společnost je tvořena svobodnými nezávislými jedinci. Jde o politické uchopení první Lukesovy kategorie - lidské jedinečnosti.

Př́klad environmentální relevance:

Klasik environmentálního myšlení H. D. Thoreau inspiruje $k$ občanské neposlušnosti, která bývá principem nenásilných radikálních tzv. př́mých akcí environmentálních hnutí (česky 1994). Dnešní profesionalizace a státní podpora environmentálním projektům prinášeji útlum environmentálních projevi̊ občanské neposlušnosti, radikálního politického individualizmu.

\section{EKONOMICKÝ INDIVIDUALIZMUS}

Odmítnutí ekonomické regulace státem. Ekonomický individualizmus se stal ekonomickou teorií, ale i normativní doktrínou, která redukuje pohled na ekonomii; zdůrazňuje význam privátního majetku, trhu a rovných př́ležitostí jedinců.

Přiklad environmentální relevance:

Stěžejní rozpor mezi liberálni ekonomii a environmentálním pohledem tkví v rozdilném pojetí základni ekonomické kategorie vzácnosti. Vzácnost odvozená z napětí mezi nabídkou 
a poptávkou na trhu není schopna vyjádřit význam a hodnotu přirodních entit, jak je dokládá biologická ekologie a environmentální etika. V pojetí environmentalistů patři př́roda $k$ hodnotám, které musejí být institucemi chráněny vĩči volnému trhu, realizovanému tržni aktivitou jedinců. V odporu k liberálnímu individualizmu jsou environmentalisté podobní nejen levicově orientovaným myslitelưm, ale i konzervativcům - skutečnost, která doposud zůstává v environmentálním myšlení bez adekvátní pozornosti (srovnej Scruton 2008).

\section{NÁBOŽENSKÝ INDIVIDUALIZMUS}

Před Bohem jsou si lidé rovni. Podle reformovaných konfesi si věrici vytvář́ $k$ Bohu osobni vztah, nepotřebuje zprostředkovatele, svědomí jedince se internalizuje. Sebezpytujicí jedinec nenachází jistotu $v$ institutu zpovědi. Náboženský individualizmus se stal podle $M$. Webera základem individualizmu ekonomického.

Príklad environmentální relevance:

Četní autoři (napřiklad White 1967) považuji individualizmus kalvínského krest'anství s jeho etikou práce za jeden ze zdrojů ekologické krize.

\section{ETICKÝ INDIVIDUALIZMUS}

Dvě základní formy:

Tzv. etický egoizmus: Cílem individuálního jednání je vlastní prospěch. City vưči bližním jsou vyvolány sebeláskou nebo představou budoucího neštěstí nás samých.

Etický individualizmus v užšim slova smyslu: Jedinec je svrchovaným arbitrem morálního hodnocení, které závisí na jeho osobním citění a percepci světa. Dá se však počítat s tím, že lidé mají približně shodnou percepci a cítění.

Př́klad environmentální relevance:

Environmentalisté redukují pojetí individualizmu tím, že jej s negativním hodnocením ztotožňují s etickým egoizmem. Druhý význam etického individualizmu však znamená možnost, že environmentálně senzitivní jedinec si vytvář́ k přirodě adekvátnějši morální postoj, než jaký mu vnucuji instituce.

\section{EPISTEMOLOGICKÝ INDIVIDUALIZMUS}

Poznání má empirickou povahu, spočivá ve zkušenosti jedince, v jeho smyslech a mysli. Menši význam má sociální rozměr sdilleného světa, jeho intersubjektivní povaha. Zastánci epistemologického individualizmu opomíjejí význam jazyka jako předpokladu a podmíněnosti poznávání, význam symbolu a mýtů v utváření vztahu k př́rodě.

Príklad environmentální relevance:

V environmentálním myšlení zatím nedošlo $k$ adekvátni diskuzi se sociálním konstruktivizmem (Eder 1996). Podle většiny environmentalistů každý jedinec může přirodu poznávat a vytvořit si k ní vztah na základě př́mé osobni smyslové zkušeností. Z této představy se odvozují např́klad metody environmentální výchovy, spočivající na zážitku v prírodě a krajině, praktiky tzv. hlubinné ekologie apod. 


\section{METODOLOGICKÝ INDIVIDUALIZMUS}

Vědecké vysvětlení celku se musi opírat o zkoumáni jeho jednotlivých elementů. Fungování sociálních institucí má být poznáváno jako výsledek postojů, rozhodnutí a jednání jednotlivců. Vysvětlení v pojmech kolektivů jsou nedostatečná. Př́stup, který většina sociologů nesdílí.

Príklad environmentální relevance:

Většina společenskovědních výzkumů zabývajícich se environmentálními tématy se opírá o metodologický individualizmus, např́klad výzkumy ekologické relevance životního způsobu domácností a jednotlivců. Méně pozornosti je věnováno zkoumání vlivu sociálních institucí. Někteři sociologové přitom upozorňuji na relativně malé možnosti jedince v ovlivnění makrospolečensky určených skutečností, jako je způsob výroby, ale právě $i$ životní způsob jedince samého.

\section{Literatura}

ADORNO, Theodor W. ; ORKHEIMER, Max. Dialektik der Aufklärung. Frankfurt/M. : Fischer Taschenbuch Verlag, 1971. 310 s. ISBN 3-436-01487-7.

BAUMAN, Zygmunt. Globalizace : di̊sledky pro člověka. 1. vyd. Praha : Mladá fronta, 1999. $157 \mathrm{~s}$. ISBN 80-2040-817-7.

BECK, Ulrich ; BECK-GERNSHEIM, Elisabeth. Individualization :Institutionalized Individualism and its Social and Political Consequences. 1. vyd. London: SAGE Publications, 2002. 221 s. ISBN 0-761-96112-7.

BEDNAŘÍKOVÁ, Jarmila. Die älteste Individualisierung und die Beziehung des Individuums zu Natur und Gesellschaft. In Sbornik praci Filozofické fakulty Brněnské univerzity N 13, 2008, s. 23 - 36. ISSN 1211-6335.

BELL, Michael Mayerfeld ; CAROLAN, Michael S. An invitation to environmental sociology. 2. vyd. Thousand Oaks, CA : Pine Forge Press, 2004. 325 s. ISBN 0-761-98775-4.

BERLIN, Isaiah. Čtyři eseje o svobodě. 1. vyd. Praha : Prostor, 1999. 332 s. ISBN 80-7260-004-4.

BROOKS, David. Bobos : nová americká elita a její styl. 1. vyd. Praha : Dokořán, 2001. 279 s. ISBN 80-8656-903-9.

BURCKHARDT, Georg E. Was ist Individualismus? : eine philosophische Einführung. Leipzig : Felix Meiner, 1913. $88 \mathrm{~s}$.

DITTMAR, Helga. The Social Psychology of Material Possessions : To Have Is to Be. New York : St. Martin's Press, 1992. 250 s. ISBN 0-745-00956-5, 0-745-00956-5.

DOBSON, Andrew. Green Political Thought. 4. vyd. London : Routledge, 2000. 225 s. ISBN 978-0-415-40352-8, 978-0-415-40351-1.

DRAŽILOVÁ, Dita. Etika zoologických zahrad : kritický pohled na zájmy zvírat, ochranu druhů a lidské zájmy. [Disertační práce]. Brno : Masarykova univerzita, Fakulta sociálních studií, Katedra environmentálních studií, 2005. 139 s.

DYAS, Sabine. Nachhaltiges Verwendungs-und Entsorgungsverhalten privater Haushalte : Realisationschancen eines neuen Konsumleitbildes in Deutschland. Wiesbaden : Deutscher Universitäts-Verlag, 2000. 250 s. ISBN 3-824-40436-2.

EDER, Klaus. The Social Construction of Nature : A Sociology of Ecological Enlightenment. London : SAGE Publications, 1996. 243 s. ISBN 0-803-97848-0, 0-803-97849-9.

FOUCAULT, Michel. Das Subjekt und die Macht. In DREYFUS, H. L., RABINOW, P. Michel Foucault : Jenseits von Strukturalismus und Hermeneutik. Frankfurt am Main, 1987, s. 265 - 294. ISBN 978-3-445-07002-9. 
FROMM, Erich. Mit nebo být? 1. vyd. Praha : Naše vojsko, 1992. 170 s. ISBN 80-206-0181-3.

HARDIN, Garrett. The Tragedy of the Commons. Science, 1968, roč. 3859, č. 162, s. 1243 - 1248.

HOBSON, Kersty. Competing Discourses of Sustainable Consumption : Does the "Rationalization of Lifestyles" Make Sense? Environmental Politics, 2002, roč. 2, č. 11, s. 95 - 120. ISSN 0964-4016. JASPERS, Karl. Duchovni situace doby. 1. vyd. Praha : Academia, 2008. 191 s. ISBN 978-80-200-1646-1.

JOHANISOVÁ, Nad'a. Living in the Cracks : A Look at Rural Social Enterprises in Britain and the Czech Republic. 1. vyd. Dublin : Feasta, 2005. 133 s. ISBN 1-903-99852-2.

KANT, Immanuel. Základy metafyziky mravio. 1. vyd. Praha : Svoboda, 1976. $135 \mathrm{~s}$.

KELLER, Jan. Až na dno blahobytu. Brno : Hnutí Duha, 1993. 127 s.

KELLER, Jan. Dějiny klasické sociologie. 1. vyd. Praha : Sociologické nakladatelství, 2004. 529 s. ISBN 8-086-42934-2.

KELLERT, Stehen R. ; WILSON, Edward O. (eds.). The Biophilia hypothesis. 13. vyd. Washington, D.C. : Island Press, 1993. 484 s. ISBN 1-559-63148-1, 1-559-63147-3.

KOHÁK, Erazim. Zelená svatozár̆ : kapitoly z ekologické etiky. 1. vyd. Praha : Sociologické nakladatelství, 1998. 203 s. ISBN 8-085-85063-X.

KOMÁREK, Stanislav. Obraz člověka a př́rody v zrcadle biologie. 1. vyd. Praha : Academia, 2008. 325 s. ISBN 978-8-020-01592-1.

KONVIČKA, Martin. Pohřbíme konečně ekosystém? Vesmír, 2002, roč. 81 (132), č. 3, s. 127 - 129. ISSN 1214-4029.

KRAMOSILOVÁ, Jiřina. Knihy o Anastasii a myšlenka rodových osad v České republice v kontextu některých současných ideologických a environmentálních koncepti̊. [Připravovaná diplomová práce]. Brno : Masarykova univerzita, Fakulta sociálních studií, Katedra environmentálních studií, 2009.

KRAUTOVÁ, Zuzana. Spotřeba domácností a proces individualizace v environmentální perspektivě. Sociální studia, 2009, roč. 6, č. 3, s. 31 - 57. ISSN 1214-813X.

KRISTELLER, Paul Oskar. Die Philosophie des Marsilio Ficino. 1. vyd. Frankfurt am Main : Klostermann, 1972. 452 s. ISBN 978-3-465-00886-6.

KYSUČAN, Lubor. Individuum versus antická ekotopie. In Minerva : Odborný periodický sborník společenských věd. Sv. 3., 2007, s. 48 - 56. ISBN 978-8-073-94022-5.

LEOPOLD, Aldo. Obrázky z chatrče a rozmanité poznámky. 1. vyd. Tulčík: Abies, 1999. 269 s.

LIBROVÁ, Hana. Individualizace v environmentální perspektivě : sociologické rámování mění pohled a plodí otázky. Sociologický časopis, 2009, roč. 45. ISSN 0038-0288. [odevzdáno v záŕí 2008, v recenzním řízení].

LIBROVÁ, Hana. Láska ke krajině? 1. vyd. Brno : Blok, 1988. 165 s.

LIBROVÁ, Hana. Pestř́ a zelení : kapitoly o dobrovolné skromnosti. 1. vyd. Brno : Veronica, 1994. 217 s. ISBN 8-085-36818-8.

LIBROVÁ, Hana. Protipřírodní subkultura : plod civilizace, ideová opozice, estetická póza. In STIBRAL, K., DADEJÍK, O. (eds.). Př́roda, krása, krajina. Praha, 2009. [v tisku].

LIBROVÁ, Hana. Vlažní a váhavi : kapitoly o ekologickém luxusu. 1. vyd. Brno : Doplněk, 2003. 319 s. ISBN 8-072-39149-6.

LIPOVETSKY, Gilles. Paradoxni štěstí : esej o hyperkonzumni společnosti. 1. vyd. Praha : Prostor, 2007. 448 s. ISBN 978-80-7260-184-4.

LUKES, Steven. Individualism. 1. vyd. Colchester : Basil Blackwell, ECPR Press, 2006. 141 s. ISBN 0-954-79666-7.

NAESS, Arne. Ekologie, pospolitost a životni styl : náčrt ekosofie. 1. vyd. Tulčík : Abies, 1996. $310 \mathrm{~s}$. ISBN 80-886-9909-6.

PELIKÁN, Vojtěch. Individualizace, individualismus a environmentální témata v sociologické a environmentalistické literatuře. Sociálni studia, 2009, roč. 6, č. 3, s. 79 - 95. ISSN 1214-813X. 
PETRUSEK, Miloslav. Společnosti pozdni doby. 1. vyd. Praha : Sociologické nakladatelství, 2006. 459 s. ISBN 80-864-2963-6.

PORTMANN, Adolf. Přežití a zjevnost. In KLEISNER, K. (ed.). Biologie ve službách zjevu : $k$ teoreticko-biologickým myšlenkám Adolfa Portmanna. Červený Kostelec : Pavel Mervart, 2008. s. 57 - 65. ISBN 978-80-868-1864-1.

RATZINGER, Joseph ; SEEWALD, Peter. Křest’anství na přelomu tisíciletí. 2. vyd. Praha : Portál, 2005. 198 s. ISBN 80-736-7016-X.

RAY, Paul H. ; ANDERSON, Sherry Ruth. The Cultural Creatives : How 50 Million People Are Changing the World. New York: Three rivers press, 2000. 370 s. ISBN 0-609-80845-1.

RIDLEY, Matt. Pưvod ctnosti : o evolučních základech a zákonitostech nesobeckého jednáni člověka. 1. vyd. Praha : Portál, 2000. 295 s. ISBN 80-717-8351-X.

RIEGL, Alois. Nové směry v památkové péči. In RIEGL, A. Moderni památková péče. Praha : Národní památkový ústav, ústřední pracoviště, 2003, s. 77 - 99. ISBN 80-862-3434-7.

RØPKE, Inge. The Dynamics of Willingness to Consume. Ecological Economics, March 1999, roč. 28, č. 3, s. $399-420$. ISSN 0921-8009.

ROUSSEAU, Jean-Jacques. Júlia, alebo, Nová Heloisa. 1. vyd. Bratislava : Tatran, 1982. $712 \mathrm{~s}$.

ROUSSEAU, Jean-Jacques. Vyznání. 3. vyd. Praha : Odeon, 1978. 544 s.

SANNE, Christer. Willing Consumers-or Locked-in? Policies for a sustainable consumption. Ecological Economics, 2002, roč. 42, č. 1-2, s. 273 - 287. ISSN 0921-8009.

SCHMID, Wilhelm. Glück. Frankfurt : Insel Verlag, 2007. 79 s. ISBN 3-458-17373-0.

SCHMID, Wilhelm. Philosophie der Lebenskunst : eine Grundlegung. 1. vyd. Frankfurt am Main : Suhrkamp, 1998. 566 s. ISBN 978-3-518-28985-3.

SCHMID, Wilhelm. Schönes Leben? : Einführung in die Lebenskunst. Frankfurt am Main : Suhrkamp, 2000. 182 s. ISBN 3-518-41207-8, 978-3-518-41207-7.

SCRUTON, Roger. Ochrana prŕrody jako konzervativní téma. In Bulletin Občanského institutu č. 208. Praha : Občanský institut, 2008, s. 3 - 15. ISBN 978-80-869-7239-8.

SIMMEL, Georg. Soziologie. Untersuchungen über die Formen der Vergesellschaftung. 2. vyd. Leipzig, München : Duncker und Humblot, 1922. 578 s.

SUŠA, Oleg. Životní prostředí a odpovědnost : individuální volba, komunikace, institucionální rizika. Filosofický časopis, 1997, roč. 45, č. 2, s. 426 - 441. ISSN 0015-1831.

TAYLOR, Paul W. Respect for Nature : A Theory of Environmental Ethics. Princeton : Princeton University Press, 1986. 342 s. ISBN 978-0-691-02250-5.

THOREAU, Henry David. Občanská neposlušnost a jiné eseje. 1. vyd. Poprad : Christina, 1994, 85 s. ISBN 80-967-3010-X.

TOMEK, Václav ; SLAČÁLEK, Ondřej. Anarchismus : svoboda proti moci. 1. vyd. Praha : Vyšehrad, 2006. 669 s. ISBN 80-702-1781-2.

VACKOVÁ, Barbora ; GALČANOVÁ, Lucie. Village?... that's when I know Everyone in the Bus (Contribution of Urban Sociology to the Research on Countryside). In MAJEROVÁ, V. (ed.). Venkov je náš svět : Countryside-Our World. 1. vyd. Praha : Česká zemědělská univerzita v Praze, 2008, s. 584 - 595. ISBN 978-80-213-1851-9.

Velký sociologický slovník. 1, A-O. 1. vyd. Praha : Karolinum, 1996. 747 s. ISBN 80-718-4164-1.

WEBER, Max. Gesammelte Aufsätze zur Religionssoziologie I. 2. vyd. Tübingen : J. C. B. Mohr (Paul Siebeck), 1922.

WHITE, Lynn Townsend, Jr. The Historical Roots of Our Ecologic Crisis. Science, 1967, roč. 155, č. 3767 , s. $1203-1207$. 


\section{Autorka}

Hana Librová, školením bioložka a socioložka, zabývá se environmentálními souvislostmi životního zpo̊sobu, od roku 1997 profesorka sociologie. Je zakladatelkou oboru humanitní environmentalistika na Fakultě sociálních studií Masarykovy univerzity. Napsala knižní publikace Sociální potřeba a hodnota krajiny (1987), Láska ke krajině? (1988), Pestři a zelení : kapitoly o dobrovolné skromnosti (1994), Vlažní a váhaví : kapitoly o ekologickém luxusu (2003).

Kontakt: librova@fss.muni.cz 